\title{
Thyroid dysfunction among type 2 diabetic female Egyptian subjects
}

\author{
This article was published in the following Dove Press journal: \\ Therapeutics and Clinical Risk Management \\ 21 November 2016 \\ Number of times this article has been viewed
}

\author{
Ibrahim N Elebrashy' \\ Amr El Meligi' \\ Laila Rashed ${ }^{2}$ \\ Randa F Salam' \\ Elham Youssef' \\ Shaimaa A Fathy' \\ 'Department of Internal Medicine, \\ Diabetes, and Endocrinology, \\ ${ }^{2}$ Department of Medical Biochemistry, \\ Faculty of Medicine, Cairo University, \\ Giza, Egypt
}

Purpose: High prevalence of thyroid disorders is more common in type 1 diabetes compared to type 2 diabetes, due to associated autoimmunity. Hypothyroidism is the most common disorder. The objective was to assess the prevalence of thyroid dysfunction among type 2 diabetic Egyptian females and to find the correlation between metabolic syndrome components and autoimmune thyroid dysfunction.

Materials and methods: The study included 62 type 2 diabetic Egyptian females and 27 sex- and age-matched controls. All patients in the study were subjected to anthropometric measures, including $\mathrm{HbA}_{1 \mathrm{c}}$, lipid profile, serum uric acid, thyroid-stimulating hormone (TSH), free triiodothyronine, free thyroxine, anti-thyroid peroxidase (TPO), antithyroglobulin (anti- $\mathrm{Tg}$ ), and thyroid ultrasound.

Results: Hypothyroidism was found in $45.2 \%$ of patients $(5.49 \pm 3.37 \mu \mathrm{IU} / \mathrm{mL})$ versus $11.1 \%$ of controls $(1.79 \pm 1.21 \mu \mathrm{IU} / \mathrm{mL})(P<0.001)$. Anti-TPO was found in $75.8 \%(347.15 \pm 244.87 \mathrm{IU} / \mathrm{mL})$ of patients versus $7.4 \%(32.89 \pm 33.26 \mathrm{IU} / \mathrm{mL})$ of controls $(P<0.001)$. Anti-Tg was found in $61.3 \%(508.03 \pm 369.16 \mathrm{IU} / \mathrm{mL})$ of patients versus $0(51.26 \pm 35.53 \mathrm{IU} / \mathrm{mL})$ controls $(P<0.001)$. A significant positive correlation was found between TSH and antithyroid antibodies (anti-Tg, anti-TPO; $P=0.002$ and $P=0.043$, respectively) and between TSH and thyroid-gland volume $(P=0.002)$ in diabetic patients. No correlation was found between any components of metabolic syndrome and thyroid antibodies in diabetic patients.

Conclusion: Autoimmune thyroid disease is more common in Egyptian women with type 2 diabetes than nondiabetic women, and thus points to a role of autoimmunity in the pathogenesis of type 2 diabetes.

Keywords: autoimmune thyroid dysfunction, TSH, anti-TPO, anti-Tg, T2 diabetes, metabolic syndrome

\section{Introduction}

Diabetes mellitus (DM) is a leading cause of death worldwide. ${ }^{1}$ In 2014 , the International Diabetes Federation estimated that 387 million people around the world had DM, and by 2035 this number is expected to rise to 592 million. $^{2}$ Such factors as sedentary lifestyle, dietary modifications, ethnicity, and obesity have led to a dramatic increase in the incidence of DM, especially in the twenty-first century. ${ }^{3}$

Thyroid disease including autoimmune thyroid disease is not uncommon. It has been reported that the prevalence of hypothyroidism was $3.7 \%$ in the NHANES study. ${ }^{4}$ In the Wickham study in the UK, the incidence of Graves disease was reported to be 100-200 cases per 100,000 population per year. The annual incidence of Hashimoto's thyroiditis worldwide is estimated to be $0.3-1.5$ cases per 1,000 persons. $^{5}$

DM and thyroid disorders have been shown to influence each other, and associations between both conditions have long been reported. It has been observed that
Correspondence: Randa F Salam

Department of Internal Medicine, Cairo

University, Cairo University Road,

Giza, Egypt

Tel +20 I0 01407278

Email randa.salam@live.com
Therapeutics and Clinical Risk Management 2016:12 1757-1762

1757

Dovepress in

http://dx.doi.org/10.2147/TCRMSI12302 (c) 1 (1) (2) 2016 Elebrashy et al. This work is published and licensed by Dove Medical Press Limited. The full terms of this license are available at https://www.dovepress.com/terms.php hereby accept the Terms. Non-commercial uses of the work are permitted without any further permission from Dove Medical Press Limited, provided the work is properly attributed. For permission for commercial use of this work, please see paragraphs 4.2 and 5 of our Terms (https://www.dovepress.com/terms.php). 
there is an increased frequency of thyroid dysfunction with advancing age and a higher prevalence of thyroid disease in women compared to men and in diabetic subjects compared to nondiabetics. ${ }^{6}$

Perros et al demonstrated an overall prevalence of $13.4 \%$ of thyroid diseases in diabetics, with the highest prevalence in type 1 DM (T1DM) females (31.4\%) and lowest prevalence in T2DM males (6.9\%). ${ }^{7}$ Thyroid disorders were found to be more common in subjects with T1DM compared to those with T2DM, due to the associated autoimmunity. Physiological and biochemical interrelationship between T2DM and autoimmune thyroid disease is now an interesting field of study. ${ }^{8}$

Few data are available on autoimmune thyroid diseases in T2DM in Egypt. Therefore, this study was carried out to find out about autoimmune thyroid dysfunction in T2DM females.

\section{Materials and methods}

This was a descriptive cross-sectional case-control study designed to analyze data from 62 T2DM Egyptian females living in iodine-sufficient area without a previously known thyroid disease and 27 sex- and age-matched nondiabetic healthy controls (age range: $29-57$ years). The patients were recruited according to inclusion and exclusion criteria from patients seen in the Diabetes and Endocrine Outpatient Clinic in Kasr Al Aini Hospital. This study was approved by the Ethics Committee of the Department of Internal Medicine, Cairo university.

Inclusion criteria were T2DM Egyptian females and duration of $\mathrm{DM} \geq 5$ years, while exclusion criteria were T1DM subjects, known history of thyroid disease, pregnancy, medications affecting thyroid-hormone levels (such as thyroid supplementation and antithyroid agents, interferon, amiodarone, lithium, corticosteroids), unstable cardiac disease, renal impairment, liver cirrhosis, and malignancies. All study subjects gave their written informed consent to participate in the study, and were submitted to proper history-taking, including duration of DM, current treatment, other comorbidities, and family history of DM and thyroid dysfunction.

Physical examination, including vital signs and general, head, neck, thyroid, extremities, chest, heart, abdominal, and neurological examination, was made. Anthropometric measures, including body mass index (calculated as weight in kilograms/height in square meters) and waist circumference, were made. The waist was measured at the midway point between the lowest rib plane and the iliac crest.

\section{Laboratory investigations}

Blood $(5 \mathrm{~mL})$ was collected from each participant in ethylenediaminetetraacetic acid tubes and mixed well. Part of it was used as whole blood for detection of $\mathrm{HbA}_{1 \mathrm{c}}$, and the remainder centrifuged at 8,000 rpm for 10 minutes, with the separated part kept frozen at $-80^{\circ} \mathrm{C}$ till analysis. The following laboratory investigations were performed: serum lipid profile (cholesterol [high- and low-density lipoprotein] and triglycerides) and serum uric acid using enzymatic assay (Boehringer, Mannheim, Germany); $\mathrm{HbA}_{1 \mathrm{c}}$ using a kit supplied by Crystal Chem, Downers Grove, IL, USA); thyroidhormone profile, including thyroid-stimulating hormone (TSH), free triiodothyronine $\left(\mathrm{FT}_{3}\right)$, and free thyroxine $\left(\mathrm{FT}_{4}\right)$, measured by enzyme-linked immunosorbent assay (DRG International, Springfield, NJ, USA) $;^{8}$ antithyroid antibodies, including anti-thyroid peroxidase (TPO) and antithyroglobulin (anti-Tg), measured by enzyme-linked immunosorbent assay (Orgentec Diagnostika GmbH, Mainz, Germany).

Thyroid ultrasound was performed on all participants by the same operator. All patients were examined in supine position with hyperextended neck using a frequency linear array transducer (7.5 MHz) Philips/ATL HDI 5,000 ultrasound, which provides adequate resolution and high penetration image. Thyroid volume was calculated by the elliptical volume formula $(0.479 \times$ length $\times$ width $\times$ height $)$ for each lobe. ${ }^{9}$ Nodules $\geq 1 \mathrm{~cm}$ in one diameter were measured. Real-time imaging of any thyroid lesions was performed using both grayscale and color Doppler techniques.

\section{Statistical analysis}

Statistical analysis was performed using SPSS (IBM, Armonk, NY, USA) version 22 and Microsoft Excel 2007. Results are expressed as means and standard deviation for quantitative data and as frequency (count) and relative frequency (percentage) for categorical data. Comparisons were done using unpaired $t$-tests. For comparison of categorical data, $\chi^{2}$ tests were performed. Correlation was assessed by Pearson' correlation coefficient. $P$-values less than 0.05 were considered statistically significant.

\section{Results}

Table 1 shows comparisons between DM patients (62) and controls (27) on clinical and anthropometric parameters. There were statistically significant differences between the two groups in weight, body mass index, waist circumference, and systolic blood pressure. Table 2 shows comparisons between 62 diabetic patients and 27 controls on all laboratory data and thyroid ultrasound (US) volume. There were highly statistically significant differences between the two groups in $\mathrm{HbA}_{1 \mathrm{c}}$, cholesterol (high- and low-density lipoprotein), uric acid, $\mathrm{FT}_{3}, \mathrm{FT}_{4}, \mathrm{TSH}$, anti-TPO, and anti-Tg. No statistically significant result was found for thyroid US volume. 
Table I Comparison between patients and controls on clinical and anthropometric parameters

\begin{tabular}{|c|c|c|c|c|c|}
\hline \multirow[t]{2}{*}{ Variables } & \multicolumn{2}{|c|}{ Patients } & \multicolumn{2}{|c|}{ Controls } & \multirow[t]{2}{*}{$P$-value } \\
\hline & Mean & SD & Mean & SD & \\
\hline Age (years) & 43.92 & 7.83 & 40.33 & 8.26 & 0.054 \\
\hline Duration (years) & 8.98 & 5.83 & - & - & - \\
\hline Height $(\mathrm{cm})$ & 156.66 & 5.72 & 158.33 & 6.49 & 0.227 \\
\hline Weight (g) & 85.85 & 14.12 & 74.06 & $|4.4|$ & 0.001 \\
\hline BMI $\left(\mathrm{kg} / \mathrm{m}^{2}\right)$ & 35.04 & 5.38 & 29.23 & 4.96 & $<0.001$ \\
\hline Waist (cm) & 110.03 & 11.68 & 98.22 & 12.06 & $<0.001$ \\
\hline Systolic BP & 123.39 & 20.8 & 110 & 17.1 & 0.004 \\
\hline Diastolic BP & 73.19 & 16.99 & 71.85 & 11.78 & 0.71 \\
\hline
\end{tabular}

Abbreviations: SD, standard deviation; BMI, body mass index; BP, blood pressure.

Among euthyroid diabetic patients (34), six (17.6\%) had both antibodies negative, eleven (32.4\%) had only anti-TPO positive, three $(8.8 \%)$ had only anti-Tg positive, and 14 (41.2\%) had both antibodies positive. Among controls that showed hypothyroidism, three (100\%) had both antibodies negative. Among those who had no hypothyroidism (24), two (8.3\%) had positive anti-TPO, as shown in Table 3.

Among diabetic patients who showed hypothyroidism (28), four (14.3\%) had negative antibodies, three (10.7\%) had only anti-TPO positive, two (7.1\%) had only anti-Tg positive, and $19(67.6 \%)$ had both antibodies positive. Among hypothyroid patients total of (28), 24 (85.7\%) showed overt hypothyroidism, while only four $(14.3 \%)$ showed subclinical hypothyroidism. There was no significant difference in thyroid-gland nodularity or nodule size between diabetic patients and controls, as shown in Table 4.

Correlations between TSH and all clinical and biochemical parameters in diabetic patients were significantly positive between TSH and anti-Tg $(P=0.002)$, anti-TPO $(P=0.043)$,

Table 2 Comparison between patients and controls on laboratory data and thyroid US

\begin{tabular}{|c|c|c|c|c|c|}
\hline \multirow[t]{2}{*}{ Variables } & \multicolumn{2}{|c|}{ Patients } & \multicolumn{2}{|c|}{ Controls } & \multirow[t]{2}{*}{$P$-value } \\
\hline & Mean & SD & Mean & SD & \\
\hline $\mathrm{HbA}_{\mathrm{Ic}}(\%)$ & 6.67 & 2.26 & 3.85 & 1.34 & $<0.001$ \\
\hline Chol (mg/dL) & 244.98 & 44.99 & 168.33 & 34.09 & $<0.001$ \\
\hline HDL (mg/dL) & 43.52 & 9.27 & 51.42 & 6.69 & $<0.00 \mathrm{I}$ \\
\hline LDL (mg/dL) & 178.16 & 49.07 & 95.16 & 40.5 & $<0.001$ \\
\hline $\mathrm{Tg}(\mathrm{mg} / \mathrm{dL})$ & 114.85 & 13.27 & 108.76 & 19.35 & 0.089 \\
\hline UA (mg/dL) & 5.87 & 1.67 & 4.27 & 1.01 & $<0.001$ \\
\hline $\mathrm{FT}_{3}(\mathrm{pg} / \mathrm{mL})$ & 1.09 & 0.74 & 3.07 & 0.56 & $<0.00 \mathrm{I}$ \\
\hline $\mathrm{FT}_{4}(\mathrm{ng} / \mathrm{dL})$ & 0.79 & 0.46 & 1.21 & 0.4 & $<0.00 \mathrm{I}$ \\
\hline $\mathrm{TSH}(\mu \mathrm{U} / \mathrm{mL})$ & 5.49 & 3.37 & 1.79 & 1.21 & $<0.00$ I \\
\hline Anti-Tg (IU/mL) & 508.03 & 369.16 & 51.26 & 35.53 & $<0.001$ \\
\hline Anti-TPO (IU/mL) & 347.15 & 244.87 & 32.89 & 33.26 & $<0.001$ \\
\hline Thyroid US (volume) & 8.44 & 4.09 & 7.91 & 3.29 & 0.558 \\
\hline
\end{tabular}

Abbreviations: US, ultrasound; SD, standard deviation; Chol, cholesterol; HDL, high-density lipid; LDL, low-density lipid; Tg, thyroglobulin; UA, uric acid; $\mathrm{FT}_{3}$, free triiodothyronine; $\mathrm{FT}_{4}$, free thyroxine; $\mathrm{TPO}$, thyroid peroxidase. and thyroid US volume $(P=0.002)$. Correlations between both thyroid antibodies and all clinical and biochemical parameters in diabetic patients were significantly positive between TSH and anti-Tg $(P=0.002)$, as shown in Figure 1, and TSH and anti-TPO $(P=0.043)$, as shown in Figure 2.

\section{Discussion}

The high incidence of autoimmune thyroid disease in T1DM has been reported in many studies before. ${ }^{10}$ However, thyroid dysfunction in T2DM is a less explored field. Unrecognized thyroid dysfunction may worsen metabolic control and impede the management of diabetes. T2DM patients with subclinical hypothyroidism are at higher risk of complications like nephropathy and cardiovascular events. Therefore, diabetic patients need to be screened for thyroid dysfunction. ${ }^{11}$

In this study, primary hypothyroidism was found in $28(45.2 \%)$ diabetic patients $(5.49 \pm 3.37 \mu \mathrm{IU} / \mathrm{mL})$ versus three $(11.1 \%)$ controls $(1.79 \pm 1.21 \mu \mathrm{IU} / \mathrm{mL})(P<0.001)$. The results agree with other studies showing a high prevalence of hypothyroidism of $12.5 \%-32.4 \%$ in T2DM. ${ }^{12-15}$ Among the 28 hypothyroid diabetic patients, $24(85.7 \%)$ showed overt hypothyroidism, while only four (14.3\%) showed subclinical hypothyroidism. On the contrary, other studies have reported subclinical hypothyroidism as the most prevalent thyroid dysfunction in DM. ${ }^{16-24}$ However, there was no significant correlation between $\mathrm{HbA}_{1 \mathrm{c}}$ and TSH level or thyroid antibodies in diabetic patients, in agreement with Nobre et $\mathrm{a}^{25}$ but not with Billic-Komarica et al, ${ }^{26}$ who found a significant positive correlation between $\mathrm{HbA}_{1 \mathrm{c}}$ and TSH.

Altered thyroid hormones have been described in patients with diabetes, especially those with poor glycemic control. In diabetic patients, the nocturnal TSH peak is blunted or abolished, and the TSH response to thyrotropin-releasing hormone is impaired. This may be due to possible alteration of posttranslational glycosylation of thyrotropin-releasing hormone, thus affecting its biological activity. ${ }^{27}$

Reduced $\mathrm{T}_{3}$ levels have been observed in uncontrolled diabetic patients. This could be explained by impairment in peripheral conversion of $T_{4}$ to $T_{3}$ that normalizes with improvement in glycemic control. Suzuki et al attributed the abnormal thyroid-hormone levels found in DM to the presence of thyroid hormone-binding inhibitor, an inhibitor of the extrathyroidal conversion enzyme ( $5^{\prime}$-deiodinase) of $\mathrm{T}_{4}$ to $\mathrm{T}_{3} \cdot{ }^{28}$

In this study, anti-TPO was found in $75.8 \%$ $(347.15 \pm 244.87 \mathrm{IU} / \mathrm{mL})$ of diabetic patients versus $7.4 \%$ $(32.89 \pm 33.26 \mathrm{IU} / \mathrm{mL})$ of controls $(P<0.001)$. Anti-Tg was found in $61.3 \%(508.03 \pm 369.16 \mathrm{IU} / \mathrm{mL})$ of diabetic patients 
Table 3 Thyroid antibodies in patients and controls

\begin{tabular}{|c|c|c|c|c|c|c|c|c|}
\hline \multirow[t]{3}{*}{ Variables } & \multicolumn{4}{|c|}{ Patients } & \multicolumn{4}{|c|}{ Controls } \\
\hline & \multicolumn{2}{|c|}{ Normal } & \multicolumn{2}{|c|}{ Hypothyroidism } & \multicolumn{2}{|c|}{ Normal } & \multicolumn{2}{|c|}{ Hypothyroidism } \\
\hline & Count & $\%$ & Count & $\%$ & Count & $\%$ & Count & $\%$ \\
\hline \multicolumn{9}{|l|}{ Antibodies } \\
\hline Both negative & 6 & 17.6 & 4 & 14.3 & 22 & 91.7 & 3 & 100 \\
\hline Only TPO positive & 11 & 32.4 & 3 & 10.7 & 2 & 8.3 & 0 & 0 \\
\hline Only Tg positive & 3 & 8.8 & 2 & 7.1 & 0 & 0 & 0 & 0 \\
\hline Both positive & 14 & 41.2 & 19 & 67.9 & 0 & 0 & 0 & 0 \\
\hline
\end{tabular}

Abbreviations: TPO, thyroid peroxidase; Tg, thyroglobulin.

versus $0(51.26 \pm 35.53 \mathrm{IU} / \mathrm{mL})$ controls $(P<0.001)$. These results are similar to other studies. ${ }^{29-34}$ However, other studies showed that the prevalence of antithyroid antibodies in diabetic patients was comparable to nondiabetic control subjects. ${ }^{34,35}$ A significant positive correlation was found between both TPO antibodies and Tg antibodies and TSH ( $P=0.043$ and $P=0.002$, respectively) in diabetic patients. This suggests an autoimmune pathogenetic mechanism for thyroid dysfunction in the patients with T2DM, agreeing with Afkhami-Ardekani et al ${ }^{34}$ and Moslem et al. ${ }^{24}$

A total of 33 diabetic patients (53.2\%) were both antiTPO- and anti-Tg-positive. This suggests that there is much overlap between both thyroid antibodies. Among hypothyroid diabetic patients (28), four (14.3\%) had negative antibodies, three $(10.7 \%)$ had only anti-TPO positive, two $(7.1 \%)$ had only anti-Tg positive, and 19 (67.6\%) had both antibodies positive. Among euthyroid diabetic patients, eleven (32.4\%) had only anti-TPO positive, three (8.8\%) had only anti-Tg positive, and $14(41.2 \%)$ had both antibodies positive, which points out the importance of following up these patients, as they are expected to develop hypothyroidism in the future.

The exact explanation for the increased prevalence of autoimmune thyroid disease in T2DM is still not known. It is believed to be due to genetic and environmental factors, infections, and psychological stress. Another possible explanation could be the presence of GAD antibodies in

Table 4 Thyroid-gland nodularity and nodule size in diabetic patients and controls

\begin{tabular}{|c|c|c|c|c|c|c|c|}
\hline \multirow[t]{2}{*}{ Variables } & \multicolumn{2}{|c|}{ Controls } & \multicolumn{2}{|c|}{$\begin{array}{l}\text { Young } \\
\text { diabetic } \\
\text { patients }\end{array}$} & \multicolumn{2}{|c|}{$\begin{array}{l}\text { Old diabetic } \\
\text { patients }\end{array}$} & \multirow[t]{2}{*}{$P$-value } \\
\hline & Count & $\%$ & Count & $\%$ & Count & $\%$ & \\
\hline Nodularity & & & & & & & 0.821 \\
\hline No & 22 & 81.5 & 30 & 81.1 & 22 & 88 & \\
\hline Yes & 5 & 18.5 & 7 & 18.9 & 3 & 12 & \\
\hline Nodule size & & & & & & & 0.769 \\
\hline Small & 3 & 60 & 6 & 85.7 & 2 & 66.7 & \\
\hline Large & 2 & 40 & I & 14.3 & I & 33.3 & \\
\hline
\end{tabular}

some patients of T2DM. ${ }^{36}$ Autoimmune aspects in T2DM could be a possible link. It is believed that insulin resistance arises when $\mathrm{B}$ cells and other immune cells react against the self-antigens. B cells have been found to accumulate in the visceral fat of obese mice. The resulting self-antigens can trigger an autoimmune response, which in turn accelerates $\beta$-cell death.

Self-reactive $\mathrm{T}$ cells or defects in regulatory $\mathrm{T}$ cells have also been detected in autoantibody-negative T2DM patients, resulting in inflammation-induced tissue destruction. However, the extent to which inflammation overlaps with autoimmunity is not known. Recent studies have shown the importance of cytokines and chemokines in the pathogenesis of thyroid disease. In thyroid tissue, recruited T-helper 1 lymphocytes may be responsible for enhanced IFN $\gamma$ and TNF $\alpha$ production, which in turn stimulates CXCL10 (the prototype of the IFN $\gamma$-inducible T-helper 1 chemokines) secretion from the thyroid cells, thus creating an amplification-feedback loop, initiating and perpetuating the autoimmune process. ${ }^{37}$ Researchers recently found that anti-CD20, which targets and eliminates mature B cells, IL1receptor antagonists (anakinra), and a T-cell costimulation blocker (abatacept), may be beneficial in improving glucose control in T2DM. ${ }^{32}$

Correlation between thyroid dysfunction and the different parameters of metabolic syndrome could not be found

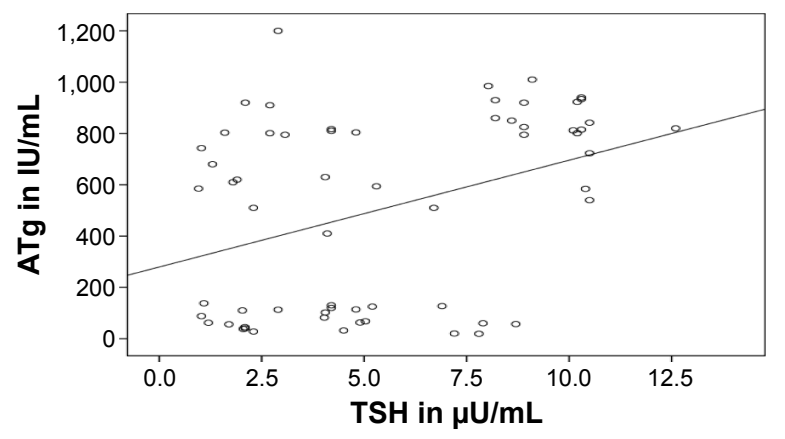

Figure I Correlation between antithyroglobulin (ATg) and thyroid-stimulating hormone (TSH). 


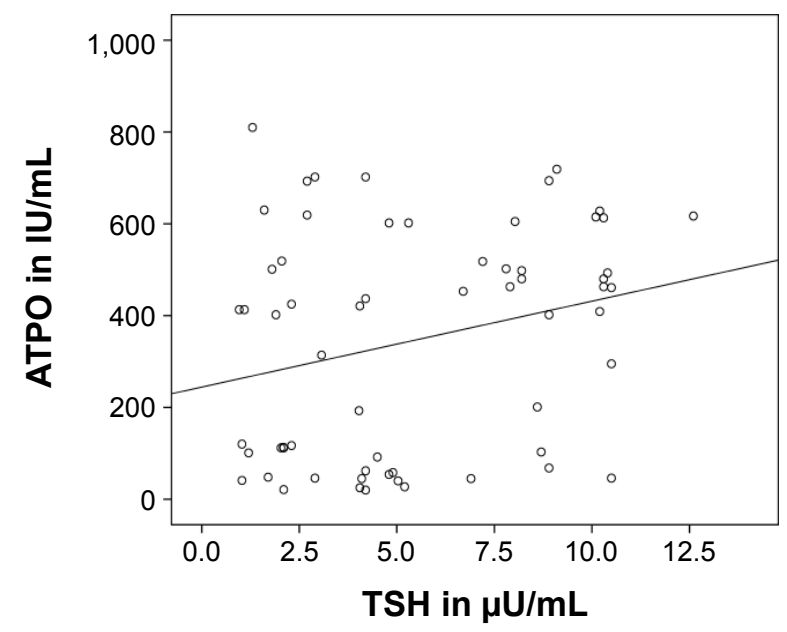

Figure 2 Correlation between anti-thyroid peroxidase (ATPO) and thyroidstimulating hormone (TSH).

in diabetic patients. On the other hand, a study involving a Chinese population found higher TSH levels in patients with metabolic syndrome compared to a non-metabolic syndrome group, suggesting that subclinical hypothyroidism may be a risk factor for metabolic syndrome. This suggests that thyroid dysfunction may increase cardiovascular disease risk in diabetic patients through interrelationships with dyslipidemia, insulin resistance, and vascular endothelial dysfunction. ${ }^{38}$

In the present study, no significant difference was found in thyroid volume or nodularity between diabetics and controls. However, there was a positive correlation between thyroidgland volume and TSH, but not with thyroid antibodies in diabetic patients. This agrees with Zakaria et al, who found that TSH induced the expression of growth factors and their receptors and may have contributed to an increased responsiveness to growth factors, which clinically manifested with larger thyroid volume and nodule formation. ${ }^{39}$

\section{Conclusion}

Hypothyroidism was found to be more common in Egyptian women with T2DM compared to controls. The significant positive correlation between both antithyroid antibodies and serum TSH in T2DM patients suggests that thyroid dysfunction in women with T2DM is due to an autoimmunemediated pathogenetic mechanism, thus elevating the role of autoimmunity in the pathogenesis of T2DM.

\section{Acknowledgment}

The abstract of this paper was presented at the ECE conference on May 28, 2016 as a poster presentation, the abstract of which was published in Endocrine Abstracts (2016), the conference book (DOI:10.1530/endoabs.41.EP1063).

\section{Disclosure}

The authors report no conflicts of interest in this work.

\section{References}

1. Faghilimnai S, Hashemipour M, Kelishadi B. Lipid profile of children with type 1 diabetes compared to controls. ARYA J. 2006;2(1):36-38.

2. International Diabetes Federation. IDF Diabetes Atlas. 6th ed. Brussels IDF; 2014

3. Zimmet P, Alberti KG, Shaw J. Global and societal implications of the diabetes epidemic. Nature. 2001;414 (6865):782-787.

4. Aoki Y, Belin RM, Clickner R, Jeffries R, Phillips L, Mahaffey KR. Serum TSH and total T4 in the United States population and their association with participant characteristics: National Health and Nutrition Examination Survey (NHANES 1999-2002). Thyroid. 2007;17(12): 1211-1223.

5. Tagami T, Tamanaha T, Shimazu S, et al. Lipid profiles in the untreated patients with Hashimoto thyroiditis and the effects of thyroxine treatment on subclinical hypothyroidism with Hashimoto thyroiditis. Endocr J. 2010;57(3):253-258

6. Feely J, Isles TE. Screening for thyroid dysfunction in diabetics Br Med J. 1979;1(6179):1678.

7. Perros P, McCrimmon RJ, Shaw G, Frier BM. Frequency of thyroid dysfunction in diabetic patients: value of annual screening. Diabet Med. 1995;12(7):622-627.

8. Granner DK. Thyroid hormones. In: Murray RK, Granner DK, Mayes PA, Rodwell VW, editors. Harper's Biochemistry. 25th ed. London: Prentice Hall; 2010:533-538.

9. Brunn J, Block U, Ruf G, Bos I, Kunze WP, Scriba PC. [Volumetric analysis of thyroid lobes by real-time ultrasound]. Dtsch Med Wochenschr. 1981;106(41):1338-1340. German.

10. Dosi RV, Tandon N. A study on prevalence of thyroid auto-immunity in type 1 diabetes mellitus. J Indian Med Assoc. 2010;108(6):349-350, 355-356.

11. Chen HS, Wu TE, Jap TS, et al. Subclinical hypothyroidism is a risk factor for nephropathy and cardiovascular diseases in type 2 diabetic patients. Diabet Med. 2007;24(12):1336-1344.

12. Ghazali SM, Abbiyesuku FM. Thyroid dysfunction in type 2 diabetics seen at the University College Hospital, Ibadan, Nigeria. Niger J Physiol Sci. 2010;25(2):173-179.

13. Papazafiropoulou A, Sotiropoulos A, Kokolaki A, Kardara M, Stamataki P, Pappas S. Prevalence of thyroid dysfunction among Greek type 2 diabetic patients attending an outpatient clinic. J Clin Med Res. 2010;2(2):75-78.

14. Díez JJ, Sánchez P, Iglesias P. Prevalence of thyroid dysfunction in patients with type 2 diabetes. Exp Clin Endocrinol Diabetes. 2011;119(4): 201-207.

15. Singh G, Gupta V, Sharma AK, Gupta N. Evaluation of thyroid dysfunction among type 2 diabetic Punjabi population. Adv Biores. 2011 2(2):3-9.

16. Demitrost $\mathrm{L}$, Ranabir $\mathrm{S}$. Thyroid dysfunction in type 2 diabetes mellitus: a retrospective study. Indian J Endocrinol Metab. 2012;16 Suppl 2: 334-335.

17. Weetman AP. Hypothyroidism: screening and subclinical disease. $B M J$ 1997;314(7088):1175-1178

18. Cooper DS. Hyperthyroidism. Lancet. 2003;362(9382):459-468.

19. Ramaswamy M, Balaraju B, Prahlad R, et al. Profile of hypothyroidism in type 2 DM in Hyderabad. $J$ Assoc Physicians India. 2003;51: $1167-1169$.

20. Radaideh AR, Nusier MK, Amari FL, et al. Thyroid dysfunction in patients with type 2 diabetes mellitus in Jordan. Saudi Med J. 2004; 25(8):1046-1050.

21. Johnson JL. Diabetes control in thyroid disease. Diabetes Spectr. 2006 19(3):148-153.

22. Palma C, Pavesi M, Nogueira V, et al. Prevalence of thyroid dysfunction in patients with diabetes mellitus. Diabetol Metab Syndr. 2013; 5(1):58. 
23. Vikhe VB, Kanitkar SA, Tamakuwala K. Thyroid dysfunction in patients with type 2 diabetes mellitus at tertiary care center. Natl J Med Res. 2013;3(4):377-380.

24. Moslem F, Bithi TS, Biswas A. Prevalence of thyroid dysfunction among type-2 diabetes patients in an urban diabetes hospital, Bangladesh. Open Sci J Clin Med. 2015;3(3):98-113.

25. Nobre EL, Jorge Z, Pratas S, Silva C, Castro JJ. Profile of the thyroid function in a population with type 2 diabetes mellitus. Endocrine Abstracts. 2002;3:298.

26. Billic-Komarica E, Beciragic A, Junuzovic D. The importance of HbA1c control in patients with subclinical hypothyroidism. Mater Sociomed. 2012;24(4):212-219.

27. Gürsoy NT, Tuncel E, Ertürk E, İmamoğlu S, Arınık A. The relationship between the glycemic control and the hypothalamus-pituitarythyroid axis in diabetic patients. Turk J Endocrinol Metab. 1999;3(4): 163-168.

28. Suzuki J, Nanno M, Gemma R, Tanaka I, Taminato T, Yoshimi T. [The mechanism of thyroid hormone abnormalities in patients with diabetes mellitus]. Nihon Naibunpi Gakkai Zasshi. 1994;70(4):465-470. Japanese.

29. Krejci H, Perusicova J. Autoimmune thyropathies in patients with diabetes mellitus 1 and type 2. DMEV. 2004;7(3):164.

30. Akbar D, Ahmed M, Al-Mughales J. Thyroid dysfunction and thyroid autoimmunity in Saudi type 2 diabetics. Acta Diabetol. 2006;43(1): 14-18.

31. Yasmin T, Ghafoor F, Malik T, et al. Pattern of thyroid autoimmunity in type 1 and type 2 diabetics. J Coll Physicians Surg Pak. 2006; 16(12):751-754.
32. Itariu B, Stulnig T. Autoimmune aspects of type 2 diabetes mellitus. Gerontology. 2014;60(3):189-196.

33. Hajieh S, Behbahani M, Mohtashami AZ. Prevalence of thyroid dysfunction and thyroid auto antibodies in type 2 diabetic patients. PakJ Med Sci. 2011;27(5):1169-1172.

34. Afkhami-Ardekani M, Rashidi M, Shojaoddiny-Ardekani A, et al. Prevalence of thyroid autoantibodies in type 2 diabetic patients. Iran $J$ Diabetes Obes. 2009;1(1):1-6.

35. Begum HA, Islam KS, Hossen R, Monirujjaman M, Ahmed S. Cooccurrence of type 2 diabetes mellitus and thyroid metabolic disorders in Bangladeshi population. Scholars J Appl Med Sci. 2014;2(2B): 605-612.

36. Witting V, Bergis D, Sadet D, Badenhoop K. Thyroid disease in insulintreated patients with type 2 diabetes: a retrospective study. Thyroid Res. 2014;7(1):2.

37. Antonelli A, Ferrari SM, Corrado A, Di Domenicantonio A, Fallahi P. Autoimmune thyroid disorders. Autoimmun Rev. 2015;14(2):174-180.

38. Lai Y, Wang J, Jiang F, et al. The relationship between serum thyrotropin and components of metabolic syndrome. Endocr J. 2011; 58(1):23-30.

39. Zakaria E, Ghanem NS, Al-Salam RF, Elshehaby AR. The thyroid gland is another victim of the insulin resistance syndrome. Med J Cairo Univ. 2012;80(1):151-158.
Therapeutics and Clinical Risk Management

\section{Publish your work in this journal}

Therapeutics and Clinical Risk Management is an international, peerreviewed journal of clinical therapeutics and risk management, focusing on concise rapid reporting of clinical studies in all therapeutic areas outcomes, safety, and programs for the effective, safe, and sustained use of medicines. This journal is indexed on PubMed Central, CAS,

\section{Dovepress}

EMBase, Scopus and the Elsevier Bibliographic databases. The manuscript management system is completely online and includes a very quick and fair peer-review system, which is all easy to use. Visit $\mathrm{http}: / / \mathrm{www}$.dovepress.com/testimonials.php to read real quotes from published authors. 